\title{
Digital Investigation of Accent Variation in Sindhi Dialects
}

\author{
Hidayatullah Shaikh, Javed Ahmed Mahar* and Ghulam Ali Malah \\ Department of Computer Science, Shah Abdul Latif University, Khairpur, Sindh, Pakistan; \\ hidayat.shaikh@salu.edu.pk, mahar.javed@gmail.com, gali@salu.edu.pk
}

\begin{abstract}
For the last decade, Sindhi has been provided with a great margin of research efforts especially in computational applications. But, the accents applied through the province have not undergone the research experiments; however, it is mandatory requisite to develop such applications before going through the speech processing applications, i.e., Text to Speech Synthesis. More than six dialects of Sindhi are found within the province, among which the dialect of Central Region is mostly applied in formal writings and communication media. The other dialects are usually used in informal spoken for routine communication. Sindhi dialects vary from one to other in terms of phonology, morphology, and syntax. The purpose of this research study is to digitally investigate the accents of Sindhi language in three dialects of Sindhi which are Lassi, Laarri and Vicholi. The acoustic digital investigation has drawn differences among the dialects on the grounds of vowel duration, pause usage, F0 peak alignment, F0 excursion size and F0 contour shape. This paper presents the calculated means values of vowel duration and its rise size implemented on the eight different classes of syllables. Empirical variations have successfully been witnessed among the taken dialects.
\end{abstract}

Keywords: Sindhi Dialects, Language Processing, Digital.

\section{Introduction}

Sindhi can be categorized into six major dialects: (1) Siro or Siraike that is spoken in the northern part of Sindh, (2) Vicholi, spoken in the central part of Sindh, (3) Larri which is spoken in the southern part of Sindh, (4) Lassi, used in lasbela and the khirther range on the western border of Sindh, (5) Thari, spoken in the eastern part of Sindh and the Sindh-Rajistan border, (6) Kachi, spoken in the Kach region of Gujrat on the southern border of Sindh. In this research study, only three dialects of Sindhi are digitally investigated which are Lassi, Laarri and Vicholi.

With respect to the phonology of Sindhi, the observation reveals that the melody and intonation of Sindhi language in these six dialects are different from each other. Therefore, it creates complications not only in understanding, recognition and translation of Sindhi language

*Corresponding author:

Javed Ahmed Mahar (mahar.javed@gmail.com) but also hinders the sound development of various components of Sindhi Speech Processing Applications.

The study of variety in Sindhi accents provides the basic information of Sindhi phonological pattern; such information can effectively be decisive for the development of different tools for Sindhi computational speech processing systems, for instance, Automatic Speech Generation, Speech Recognition, Speech Understanding, Dictionary Creation, Morphological Analysis, Part-of-Speech Tagging, Syntactic Parsing, Machine Translation and Text-toSpeech Synthesis. The collected results of this research have the fundament of computational Sindhi Speech Processing and also for Natural Language Processing.

Since ten years, many research efforts have been taken for the development of Sindhi natural language and speech processing applications, for instance, the OCR model is proposed by Noor [1], diacritics restoration are implemented 
with four different approaches by Mahar [2], the corpus of Sindhi language is prepared and compiled by Rahman [3], the application of Sindhi and Urdu TTS is developed by Shah [4], the text editor for Sindhi language is developed by Majid [5]. The accent variation in Sindhi is discussed by Bughio [6] and Mahar [7] digitally investigated the eight class of syllables of Sindhi.

This paper presents the digital investigation of three dialects of Sindh, moreover, the experimented methodology is taken alike Yeou [8] with various acoustic measurement parameters, for instance, vowel duration, pause usage, F0 peak alignment, F0 excursion size and F0 contour shape. In this paper only vowel duration and rise size are calculated for each dialect. This is preliminary work of continuing project aims to detailed analysis of the dialectal variation in Sindhi. Work on various aspects of accent variation has been carried out for many other languages like for Arabic [8] [9], for Hindhi [10] and for French [11].

\section{Material and Method}

\subsection{Material}

We have followed the experimental procedures proposed in Yeou [8]. The main goal of this project is to conduct an in depth comparison of different dialects of Sindhi, for this purpose, the rise size of syllables and the duration of each vowel is computed. The purpose of this research study is to digitally investigate the accent of Sindhi text in different dialects of Sindh. For this, we have selected fifty common declarative words for experiments; these words are collected from books and linguists. The sample list of words is shown in Table 1. The selected words are read by five male students of our university having age of twenties. Speech sample of declarative words are recorded at Radio Pakistan Khairpur by a condenser microphone connected to a computer. The signal is digitized at 6000 $\mathrm{Hz}$. The left channel of stereo waveform with resolution of 16 bit is selected and then stored on the hard disk.

\subsection{Method}

The accent of peoples belonging with different Sindhi dialects is analyzed and compared on the basis of visual displays of the waveform image. The analysis and testing process of trough and crest will examine by using the PRAAT speech analysis system and MATLAB language. It is noted that the different features of any waveform image can be analyzed and measured through PRAAT and MATLAB. Particularly, PRAAT is a scientific computer software package for the analysis of speech in phonetics.

Table 1. Sample list of words having variation in dialects of Sindh

\begin{tabular}{|c|c|c|c|c|c|}
\hline لاسي & سِري وارو & أتر ادي & و ֶֶو لــو & لازّي & معيــاري \\
\hline & & جذّهن كان & جذّهن كان & جَيدّانهكر & جيدْهانكر \\
\hline & نَذْانهُكُون & تَذْهن كان & تُذْهن كان & تيذّانهكُر & تذّهن كان \\
\hline & هُيدُّي & هُيْذَي & هيَذئي & هيَدِّانهِن & هُيدًانهن \\
\hline & مان & مان & مان & آ & 芹 \\
\hline & تَوَهَان & تُوهِان & تَّوهُان & توَ هِين & تو هِين \\
\hline & أُجُ & أَجُ & آَجُ & آَ؛ & آ \\
\hline & كيدُق & كيدُّط & كيذُط & كُدُّكُ & كُدُّطُ \\
\hline & & كِرِيهـ & تِرِيهـ & نَيهـ & نِيْهُ \\
\hline سانجر & سَوَيرَ & ساجهر & ساجهر & ساجرَ & ساجهُر \\
\hline باجاج & باجِ & بَاجَ & بَاجرَ & بَاج & بَاجُ \\
\hline
\end{tabular}


For experiments, fifty declarative words are selected having various eight classes of syllables because in Sindhi language syllables are divided into eight classes, for instance, long vowel $(\bar{V})$, consonant-long vowel $(\mathrm{C} \bar{V})$, consonant-long vowel-short vowel $(\mathrm{C} \bar{V} \mathrm{~V})$, consonantconsonant-long vowel $(\mathrm{CC} \bar{V})$, consonant-consonant-long vowel-consonant (CC $\bar{V} \mathrm{C})$, consonant-long vowelconsonant $(\mathrm{C} \bar{V} \mathrm{C})$, consonant-short vowel $(\mathrm{CV})$, consonant-short vowel-consonant-consonant (CVCC).

Initially, the F0 contour shape of fifty selected words was inspected. Because analysis and prediction of acoustic variation like pitch and duration is mandatory for the finding of linguistic features.

It is noted that, there is a short period of silent pause of $0.072 \mathrm{~s}$ before the word and $0.125 \mathrm{~s}$ after the word. The F0 rises during the accented vowel /i/ and reaches its peak towards the end of the constant /y/ of the word. The rising-falling values of word /Thiyom/ are from - 0.933 to 0.8617 . The F0 contour shape of word /Thiyom/ is shown in Figure 1.

According to phonological structure of Sindhi, there is some contrast between short and long vowel. This can be analyzed by the prosody. F0 movement is decided with the required amount of time that cannot be fully realized in a phonetically short vowel. The F0 peak of short vowel and long vowel in different positions of different classes of syllables was tested and compared. Tests were conducted separately for each speaker. The purpose of these tests is to judge the F0 variation of different syllable classes in differ-

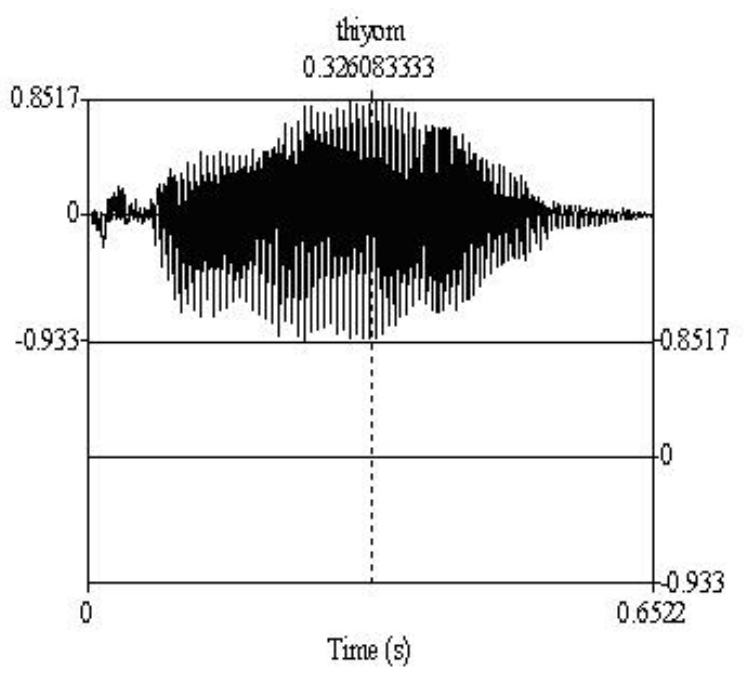

Figure 1. F0 Contour Shape of Word Thiyom. ent dialects of Sindhi. Results revealed that the F0 does not vary with syllable for each speaker.

The following segmental landmarks are described by Yeou [8]. For the measurement of F0 track, these landmarks were used and manually identified in each utterance (cf. Figure 2):

$\mathrm{C} 0$ (the onset of the stressed syllable)

V0 (the onset of the stressed vowel)

$\mathrm{C} 1$ (the end of the stressed vowel)

V1 (the onset of the following unstressed vowel)

$\mathrm{L}$ (the beginning of the $\mathrm{F} 0$ rise)

$\mathrm{H}$ (the peak of the $\mathrm{F} 0$ rise)

The F0 peak is always realized within the boundaries of the vowel. As shown in Table 2, F0 peaks are varied with the onset and the coda in the all syllable types. There is difference in $\mathrm{F} 0$ peak between the syllable classes. The peak is prior for vowels in $\mathrm{C} \bar{V} \mathrm{C}$ than in $\mathrm{C} \bar{V}$, but it is near by constant in $\mathrm{C} \bar{V} \mathrm{~V}$ and $\mathrm{CC} \bar{V} \mathrm{C}$. As an instance, if segment duration affects $\mathrm{F} 0$ peak, the mean duration values of all syllable types is also reported. Total duration of selected words was calculated having one to eight syllables.

The mean duration of mean of $\bar{V}$ is $0.337, \mathrm{C} \bar{V}$ is 0.335 , $\mathrm{C} \bar{V} \mathrm{~V}$ is $0.150, \mathrm{CC} \bar{V}$ is $0.306, \mathrm{CC} \bar{V} \mathrm{C}$ is $0.106, \mathrm{C} \bar{V} \mathrm{C}$ is $0.282, \mathrm{CV}$ is 0.205 , CVCC is 0.045 . The detailed calculated duration of vowel is shown in Table 3. Total rise size of

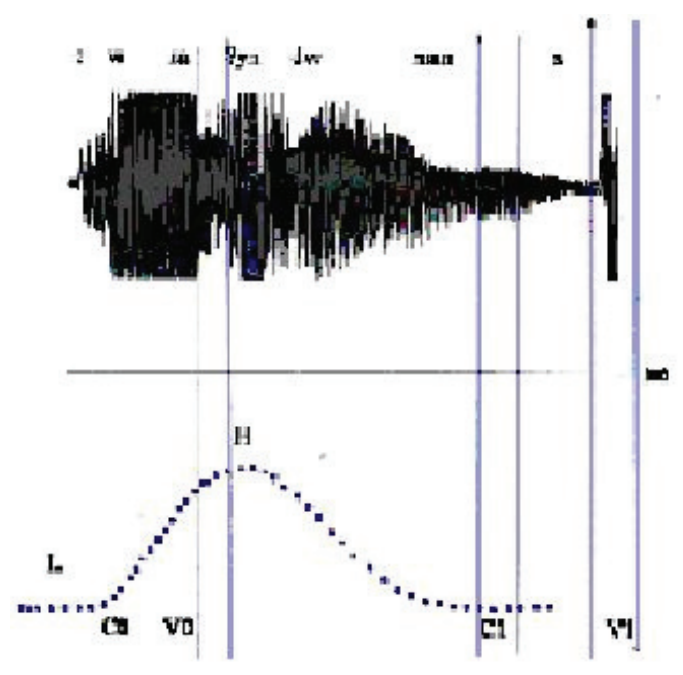

Figure 2. Waveform and F0 track showing measurement points. 
Table 2. Mean rise of syllable classes in three dialects

\begin{tabular}{|l|c|c|c|c|c|c|c|c|}
\hline \multirow{2}{*}{ Dialect } & \multicolumn{7}{|c|}{ Mean Rise Size of Different Syllables of Sindhi } \\
\cline { 2 - 10 } & $\bar{V}$ & $\mathrm{C} \bar{V}$ & $\mathrm{C} \bar{V} \mathrm{~V}$ & $\mathrm{CC} \bar{V}$ & $\mathrm{CC} \bar{V} \mathrm{C}$ & $\mathrm{C} \bar{V} \mathrm{C}$ & $\mathrm{CV}$ & $\mathrm{CVCC}$ \\
\hline Lassi & 138.9 & 148.6 & 138.7 & 119.0 & 135.5 & 113.8 & 140.3 & 132.4 \\
\hline Larri & 143.6 & 155.1 & 141.6 & 115.5 & 139.2 & 111.5 & 138.0 & 133.7 \\
\hline Utradi & 140.2 & 152.3 & 137.8 & 112.6 & 134.7 & 109.6 & 135.5 & 132.9 \\
\hline Mean of the Mean & $\mathbf{1 4 0 . 9}$ & $\mathbf{1 5 2 . 0}$ & $\mathbf{1 3 9 . 4}$ & $\mathbf{1 1 5 . 7}$ & $\mathbf{1 3 6 . 5}$ & $\mathbf{1 1 1 . 7}$ & $\mathbf{1 3 7 . 9}$ & $\mathbf{1 3 3 . 0}$ \\
\hline
\end{tabular}

Table 3. Mean vowel duration of syllable classes in three dialects

\begin{tabular}{|l|c|c|c|c|c|c|c|c|}
\hline \multirow{2}{*}{ Dialect } & \multicolumn{7}{|c|}{ Mean Vowel Duration in Different Syllables } \\
\cline { 2 - 10 } & $\bar{V}$ & $\mathrm{C} \bar{V}$ & $\mathrm{C} \bar{V} \mathrm{~V}$ & $\mathrm{CC} \bar{V}$ & $\mathrm{CC} \bar{V} \mathrm{C}$ & $\mathrm{C} \bar{V} \mathrm{C}$ & $\mathrm{CV}$ & \multirow{2}{*}{$\mathrm{CVCC}$} \\
\hline Lassi & 0.336 & 0.334 & 0.151 & 0.308 & 0.107 & 0.285 & 0.205 & 0.083 \\
\hline Larri & 0.342 & 0.340 & 0.153 & 0.309 & 0.108 & 0.295 & 0.206 & 0.033 \\
\hline Utradi & 0.335 & 0.331 & 0.148 & 0.301 & 0.103 & 0.266 & 0.204 & 0.021 \\
\hline Mean of the Mean & $\mathbf{0 . 3 3 7}$ & $\mathbf{0 . 3 3 5}$ & $\mathbf{0 . 1 5 0}$ & $\mathbf{0 . 3 0 6}$ & $\mathbf{0 . 1 0 6}$ & $\mathbf{0 . 2 8 2}$ & $\mathbf{0 . 2 0 5}$ & $\mathbf{0 . 0 4 5}$ \\
\hline
\end{tabular}

selected words was calculated having one to eight syllables. The mean rise size of mean of $\bar{V}$ is $140.9, \mathrm{C} \bar{V}$ is $152.0, \mathrm{C}$ $\bar{V} \mathrm{~V}$ is $139.4, \mathrm{CC} \bar{V}$ is $115.7, \mathrm{CC} \bar{V} \mathrm{C}$ is $136.5, \mathrm{C} \bar{V} \mathrm{C}$ is 111.7 , $\mathrm{CV}$ is $137.9, \mathrm{CVCC}$ is 133.0 . The detailed calculated duration of vowel is shown in Table 2.

It is noted that, if the duration of vowel increases then F0 peak is also increases. But if a vowel is lengthened then peak delay values tends to decrease. The F0 peak is much delayed with open syllable than with closed syllable. The rise size is higher when $\bar{V}$ is pronounced after the consonant only. When $\bar{V}$ is pronounced after two consonants, the rise size is smaller. Similarly, when $\mathrm{V}$ is pronounced after the consonant then the rise size is higher but $\mathrm{V}$ is pronounced after the $\bar{V}$ then the rise size is smaller.

\section{Conclusion}

We have presented a comparative analysis of duration and rise size of the short and long vowels of fifty selected words of three dialects of Sindhi i.e., Lassi, Larri and Vicholi. It has been observed that the into national tune becomes different due to the placement of short and long vowel in a word; even it is pronounced by same speaker.
This is an introductory work of continuing task having aim to provide detailed analysis of the dialectal variation in Sindhi including the phonological studies.

\section{References}

1. Noor A S (2009). An OCR model for Arabic style scripting thematic structures, $\mathrm{PhD}$ Thesis, Department of Computer Science, Shah Abdul Latif University, Khairpur, Sindh, Pakistan.

2. Mahar J A (2012). Statistical approaches to diacritics restoration in Sindhi text to speech synthesis system, Ph. D Thesis, Hamdard University, Karachi, Pakistan.

3. Rahman M U (2010). Towards Sindhi Corpus Construction, Conference on Language and Technology, Lahore, Pakistan.

4. Shah A A, Ansari A W, et al. (2004). Bi-Lingual Text to Speech Synthesis System for Urdu and Sindhi, National Conference on Emerging Technology, 126-130.

5. Majid B (2006). Available from: www.fileguru.com/apps/ mb-sindhi-software

6. Bughio M Q (2009). Stratification of /r/ pronunciation in Sindhi, spoken in Sindh, Pakistan, International Research Journal of Arts \& Humanities, vol 37(37), 29-48. 
7. Mahar J A, Memon G Q et al. (2009). Perception of Syllables Pitch Contour in Sindhi Language, Proceeding of the IEEE Natural Language Processing and Knowledge Engineering, Dalian, China, 593-597.

8. Yeou M, Embarki M et al. (2007). Contrastive focus and F0 patterns in three Arabic dialects, Nouveaux Cahiers de Linguistique Francaise, vol 28, 317-326.

9. Yeou M, Embarki M et al. (2007). F0 alignment patterns in Arabic dialects, $16^{\text {th }}$ International Congress of Phonetic Science, 1493-1496.
10. Mishraa D, and Bali K (2011). A Comparative Phonological Study of the Dialects of Hindhi, the $17^{\text {th }}$ International Congress of Phonetic Sciences XVII, 1390-1393.

11. Dimulescu B V, and Mareüil P B (2006). Perceptual identification and phonetic analysis of 6 foreign accents in French, INTERSPEECH - International Conference on Spoken Language Processing, 441-444. 